\title{
The Memoir and Representations of the Self: New Books by Vlasopolos and Picard
}

\author{
Ralph Freedman \\ Princeton University
}

Follow this and additional works at: https://docs.lib.purdue.edu/clcweb

Part of the Comparative Literature Commons, and the Critical and Cultural Studies Commons

Dedicated to the dissemination of scholarly and professional information, Purdue University Press selects, develops, and distributes quality resources in several key subject areas for which its parent university is famous, including business, technology, health, veterinary medicine, and other selected disciplines in the humanities and sciences.

CLCWeb: Comparative Literature and Culture, the peer-reviewed, full-text, and open-access learned journal in the humanities and social sciences, publishes new scholarship following tenets of the discipline of comparative literature and the field of cultural studies designated as "comparative cultural studies." Publications in the journal are indexed in the Annual Bibliography of English Language and Literature (Chadwyck-Healey), the Arts and Humanities Citation Index (Thomson Reuters ISI), the Humanities Index (Wilson), Humanities International Complete (EBSCO), the International Bibliography of the Modern Language Association of America, and Scopus (Elsevier). The journal is affiliated with the Purdue University Press monograph series of Books in Comparative Cultural Studies. Contact: <clcweb@purdue.edu>

\section{Recommended Citation}

Freedman, Ralph. "The Memoir and Representations of the Self: New Books by Vlasopolos and Picard." CLCWeb: Comparative Literature and Culture 4.3 (2002): <https://doi.org/10.7771/1481-4374.1167>

This text has been double-blind peer reviewed by $2+1$ experts in the field.

The above text, published by Purdue University Press (CPurdue University, has been downloaded 1188 times as of 11/ 07/19. Note: the download counts of the journal's material are since Issue 9.1 (March 2007), since the journal's format in pdf (instead of in html 1999-2007).

This document has been made available through Purdue e-Pubs, a service of the Purdue University Libraries. Please contact epubs@purdue.edu for additional information.

This is an Open Access journal. This means that it uses a funding model that does not charge readers or their institutions for access. Readers may freely read, download, copy, distribute, print, search, or link to the full texts of articles. This journal is covered under the CC BY-NC-ND license. 


\section{PURDUE}

UNIVERSITY PRESS <http://www.thepress.purdue.edu>

\section{CLCWeb: Comparative Literature and Culture}

ISSN 1481-4374 <http://docs.lib.purdue.edu/clcweb> Purdue University Press @P Purdue University

CLCWeb: Comparative Literature and Culture, the peer-reviewed, full-text, and open-access learned journal in the humanities and social sciences, publishes new scholarship following tenets of the discipline of comparative literature and the field of cultural studies designated as "comparative cultural studies." In addition to the publication of articles, the journal publishes review articles of scholarly books and publishes research material in its Library Series. Publications in the journal are indexed in the Annual Bibliography of English Language and Literature (Chadwyck-Healey), the Arts and Humanities Citation Index (Thomson Reuters ISI), the Humanities Index (Wilson), Humanities International Complete (EBSCO), the International Bibliography of the Modern Langua-ge Association of America, and Scopus (Elsevier). The journal is affiliated with the Purdue University

Press monog-raph series of Books in Comparative Cultural Studies. Contact: <clcweb@purdue.edu>

\section{CLCWeb Volume 4 Issue 3 (September 2002) Book Review Article} Ralph Freedman,

"The Memoir and Representations of the Self: New Books by Vlasopolos and Picard" <http://docs.lib.purdue.edu/clcweb/vol4/iss3/6> 


\section{Ralph FREEDMAN}

\section{The Memoir and Representations of the Self: New Books by Vlasopolos and Picard}

In this review article I discuss Anca Vlasopolos's No Return Address. A Memoir of Displacement (New York: Columbia UP, 2000) and Hans Rudolf Picard's Zwischen Chaos und Kosmos. Versuch eines Lebens im 20. Jahrhundert (Konstanz: n.p., 2002). Today, memoirs are the rage: politicians, generals, film and television stars, sports luminaries, CEOs, academics, etc., feel at least obligated to express their need for self-promotion in this venerable genre. In the history of the genre, St. Augustine proposes to guide the reader to God in his Confessions and Rousseau intends to represent himself as a human paradigm, "un homme dans toute la vérité de la nature," for example. As a serious form -- apart from its abuse by the merely ambitious and exhibitionist -- it is part equally of the mainstream of Western culture while still related in many important ways to St. Augustine and Rousseau. Memoirs reflect a canvas of recollected experience, portraying the world as enriching or impoverishing, as promoting the self or threatening it, or presenting it as a labyrinth through which the author as narrator is distilled as a determining consciousness.

The term "memoir" has been applied to any autobiography, yet strictly speaking, memoirs are autobiographies of a special kind. While autobiographies usually relate the author's career from birth to maturity or old age, stressing exploits and achievements, memoirs tend to focus on specific occasions or themes. Both are reflections of a struggling self, but in this more limited sense, memoirs suggest a closer kinship with the reflective first-person novel, the only perceptible difference being the criterion of truth. Many problems and events in people's lives can give rise to memoirs, indeed, to clusters of memoirs on related themes: themes peculiar to women's lives, themes of confession and religious awakening, or themes about the horrors of the 1930s, '40s, and beyond, penned by both perpetrators and victims. If it were not for the medium of the memoir that links us closely with visionary monologues evoking that period, our sense of that still unforgotten world would be sadly deficient. Displacement is an overwhelming twentieth-century experience which touches a raw nerve of many memoirs of our time. Sometimes the relationship between the remembered and recreated self is extraordinarily close. For example, two novels by Edith Baer, A Frost in the Night (Farrar Straus \& Giroux, 1998) and Walk the Dark Streets (Farrar Straus \& Giroux, 1999), are actually personal memoirs of different moments of her own experience, of growing up in Germany before and during the Nazi period. Her protagonist, Eva Bentheim, is the author's transparent alter ego. Her world is that of interaction between the remembered self and recreated space; but the work is no different, essentially, from outright memoirs covering the same territory.

Memoirs, then, need not present exhaustive accumulations of details as long as the moments they dramatize are concrete and meaningful. A brilliant example depicting the dislocations of the 1940s and beyond -- the story of inner and outer displacement -- through a strikingly formed vision of his life is Primo Levi's The Periodic Table (Trans. Raymond Rosenthal. Schocken Books, 1984). Levi's memoir succeeds in encapsulating the author's life in wartime and postwar Italy, and in involuntary exile. Through selected symbols of his profession, Levi produces ultimately an extraordinary "novel." The symbols, different chemical elements from the periodic table, represent significant moments or phases in Levi's life, evoking, from within his profession, an array of pictures designed to illuminate his depersonalized vision of himself. The result is akin to poetry and self-conscious narrative fiction. Levi had focused exclusively on his Auschwitz experience in two previous books, If this is a Man (Orion P, 1959) and The Truce (Schocken Books, 1965), but it is in this small book of little more than two hundred pages that he catches not just the center of his life in Auschwitz and beyond but the whole of his life to date arranged around Auschwitz as its core. The chemical symbols present themselves as indices of a formidable and an unforgettable experience of his country, his generation, and his Jewishness caught in the chemistry of himself.

The memoir in the broader and deeper sense of the genre is, of course, not confined to a particular historical position or to a sense of displacement on either side. A German book published recently and not yet translated into English, develops a complex pattern of remembrances, scenes of reflection, and encounters in a self-consciously literary way, applying just this development to 
the pilgrimage of a young man (the author) from unapologetic acceptance of the totalitarian regime to an ultimate vision of a liberal and literary ideal. Entitled Zwischen Chaos und Kosmos (Between Chaos and Cosmos), it is a particularly generous "backward glance" by Hans Rudolf Picard, a professor of French at the University of Konstanz. It is also almost a textbook on the composition of memoirs. As the title suggests, the book represents the self in two stages, placing the author between his childhood, adolescence, and young manhood, dedicated to service and loyalty to the state and a commitment to the society and its values in which he grew up, and which his parents, family, and friends shared, leading to a further set of values which only gradually distills itself from his past allegiance. The collapse of Picard's world in the spring of 1945 marks the break in his society that shows itself to the underage anti-aircraft gunner as increasing disorder. The different episodes and vignettes of his young life in which he struggled manfully for coherence gradually build to a pattern that achieves that cohesion in his adult career. As after the war the subject of this memoir becomes a teacher in a Gymnasium (German high school), marries a like-minded French colleague, serves for some years as cultural ambassador to Spain, and ends as a university professor, his cultural vision gradually solidifies. The memoir that began as a traditional Bildungsroman -- a young man growing up in an increasingly aggressive and stratified environment -- becomes a special claim for a vision that supersedes it. His passion for and accomplishments in music and poetry, both consumed and created, establish for him a new set of attitudes and beliefs, which function as a new world that retroactively imposes itself on the shattered remains of the Third Reich.

Still, as one reads this engaging book one rarely meets the ghosts that trouble Primo Levi's "periodic table" or Edith Baer's personal novels. Not only do Jews hardly exist in the young Picard's universe -- the only trenchant image is his childhood recollection of an evicted Jewish family sitting disconsolately on the sidewalk among their belongings -- but Auschwitz and other camps and even the holocaust are also rarely mentioned. Picard's genuine struggle for a new identity must undergo vast social insecurities in a bomb-scarred world. Yet, Zwischen Chaos und Kosmos is grounded firmly in the upper-class establishment whose privileged status opened up the aesthetic and professional alternatives on unquestionably solid grounds.

The dialectic that turns displacement on its head by resolving it in the end is more clearly apparent on the victims' side. A case in point is the memoir of a daughter of the generation destroyed by German oppression during World War II and, in its aftermath, by communist repression. Although, like Picard's memoir, it is written retroactively from the position of a "cosmos" following the self's pilgrimage to a university professorship, No Return Address, an extraordinarily clear-sighted work of self-discovery by Anca Vlasopolos, addresses itself to the struggle of her generation and that of her parents with poetic resonance and depth. The book is subtitled $A \mathrm{Mem}$ oir of Displacement, and both parts of the title indicate the insecurity of the remembering self. The narrator-author is a refugee from Romania where she grew up under communism, a restrictive society that followed soon after the liberation from Nazism. Vlasopolos's mother was Jewish, a former prisoner at Auschwitz, her father Greek, an original communist activist who soon became a victim of the establishment. Vlasopolos's tale of her childhood and adolescence, which takes up a large part of the book, is seen in moments of remembrance that relate as a tapestry of imagery following its own logic rather than that of time and place. Her evocation of self begins in Paris, her and her mother's temporary shelter, a way station on their emigration to the United States, and a no-man's-land between her origin in Bucharest and her destination of Detroit: "I remember returning to Paris after an absence of seven years, Paris not the city of light but the site of my first acute consciousness of cultural displacement; I stood on a metro platform, and as the train made its breakneck approach, the fumes from the tracks, loaded with strangulating memories of my first encounter with the West, rush upon my whole being with greater speed and more impact, more lasting impact at any rate, than the bullet-shaped locomotive would have had" (Vlasopolos 1; with regard to escape from the holocaust in Central and Eastern Europe and finding refuge in the US, see also Susan Rubin Suleiman's Budapest Diary: In Search of the Motherbook [Lincoln: University of Nebraska Press, 1997]; for a review article of the book, see Steven Totosy, "Memories of Hun- 
gary: A Review Article of New Books by Suleiman and Teleky," CLCWeb: Comparative Literature and Culture: A WWWeb Journal 1.1 [1999]: <http://docs.lib.purdue.edu/clcweb/vol1/iss1/7/>).

As Vlasopolos renders through the memory of the adult chronicler the story of a girl growing to womanhood in a hostile environment, her book, too, similar to Zwischen Chaos und Kosmos, becomes a modern-day Bildungsroman, but it is more than that. It is also a book about the deprivation of Eastern Europe by the holocaust and how the parents' memory of it has shaped the next generation. Born in 1948, Vlasopolos relives that time through her mother, to whom the book is dedicated and for whom it was written. For the author and remembering daughter, her mother's memory of Auschwitz, a purgatory recalled in graphic detail, forms a very large dimension, a bond that unites them for the rest of their lives. From childhood on, Vlasopolos understands more and more how deeply the world had changed for her mother since her joyful "second birthday" -- her liberation by the Soviets -- and how it had soon descended again into oppression and deprivation. This condition and feeling of constant apartness is mirrored in Vlasopolos's childhood stories; a favorite food shop, located next to a swallow's nest, was destroyed by the authorities simply for its success, the space bricked up from one day to the next. In a brilliant move, the author brought together the Turkish owner, the swallows, and what she perceived to be her simultaneous estrangement and entrapment in a single image. As the child Anca watched the swallow feeding her young, she also thought of occasions when sparrows take over a swallow's nest. Then the swallows would congregate for miles around to wall in the invaders with clay carried in their beaks. The adult author mused: "We, too, Armenians, Greeks, Jews, Turks, wanderers brought by triumphant empires or diasporas and abandoned on this hostile shore -- people whose dearly bought savoir faire oiled the wheels of commerce and kept cottage industries alive. ... found ourselves deprived of the very rootlessness that made us Other, immured inside the boundaries of a country that would let us neither out nor in" (48-49).

At a time and circumstance when food became of overwhelming importance, Vlasopolos was compelled early in her young life to see her father, whom she loved, disappear inexplicably twice from her view. First, he was imprisoned and reappeared one year later; then he vanished permanently after three years at his death. Although in both instances her mother tried to keep the truth from her daughter by telling her that her father was recovering in a spa named Herculane for his rheumatism, the mother fails in both instances. In the first instance Anca was too young not to wonder, but in the second she saw through the deception though even by then she was only eight years old. The scene in which the young girl finds herself face to face with the certain knowledge of the death of the father she loved well is unforgettably drawn. Such was the pattern of a life this fine memoir presents: a girl plays with her friends, indulges in pranks, and yet is made aware again and again of a threatening darkness hovering nearby. As she becomes a woman in exile, the nature of the darkness changes, but its threat remains.

In a fine review of No Return Address by Robert Eagelstone in the Times Literary Supplement (26 January 2002), the reviewer distinguishes perceptively between three displacements -- political, cultural, and gender-related -- that occur in No Return Address. The political displacement includes the mother's postwar exile in communist Romania, which eventually led to their migration to America when Anca was fourteen. But even before that crucial decision, exile was all around her, and had been since the time she remembered! She was very young when her father had warned her about the security police, police cells, and of sinister tunnels beneath the city's pavement where people were tortured, where normal life had no place: "Whenever I'm on this street," Vlasopolos recalled her father's voice, "I feel as if I were walking on souls in agony" (22). The fact that she retained these words until middle age indicates how ingrained fear and isolation had become in her mind. The adult writer was also keenly aware of a cultural displacement: in her chapter, "Post-Holocaust, East European, Assimilated Jewish Identity," Vlasopolos felt set apart from the militantly secular Romanian regime and in the West she would also experience an analogous displacement. Finally, Eaglestone notes Vlasopolos's displacement as a woman in a male-oriented society, extending from her Romanian origins to her later life. Choosing herself and her gender as the focus of the book, Vlasopolos has produced, in the deepest sense, a feminist work. 
It is in this self-identification with her gender that No Return Address achieves its greatest depth as a memoir. The book abounds in female characters, many of them attractive, some despicable, but many more suggesting acts of heroism and selflessness. At the same time, Vlasopolos draws patterns of female enslavement. Her mother spent hours in front of the prison waiting in deep snow with a package of warm clothes for her husband. She was let in and allowed to deliver it only after she waved the signed permission slip in the air, which convinced the sadistic male guards that it might be advisable to let her in. Her male friend, who accompanied her, dissolved with fright. "My childhood," writes Vlasopolos towards the end of her book, "was populated by women who lived with daily choices between integrity and survival" (199). Under communism the situation of women made them into an extension of their husbands' punishment, a purer and more brutal form, Vlasopolos suggests, of how women fare in the West. One woman she calls Hetta, who was expelled from the Party immediately upon her husband's arrest, was reduced to accepting half her pay for the same work and bore the burden of a demented mother and a seriously ill brother as well as a husband who was doing five years' hard labor and needed special packages of food and clothing to keep him alive. One person after another in this long train of women had suffered and had to undergo some sacrifice imposed by men for men. But it was not only as a result if their husbands' penalties that women suffered and were sometimes rescued. Vlasopolos's mother, who held an important post as a translator of subtitles for foreign movies, lost her job immediately when she and her daughter applied for a visa to America, yet they were sustained by women (and some men) who helped her work clandestinely. The adult author expresses her strong sense of female identity on the final pages of the book by her portrayal of the grace of many women who became role models even as they suffered from being oppressed by a male-dominated society and state and by the moving homage she pays to her mother. The chronicle of repression and displacement, which this book represents, is also an honest chronicle. It is not only about growing up from childhood into womanhood in the communist East, but it is also about disappointment and increasing ambivalence in the West, first in Europe (principally in France and Belgium), then in the United States, epitomized, as Vlasopolos points out in her introduction, in the cities that define each: Bucharest, Paris, and Detroit. Brilliantly, the narrator/author reflects these different levels of time, place, and perspective simultaneously in a way that is especially striking at the beginning and again at the end of the book.

Through an intensely poetic style, a very different structure emerges from that of Zwischen Chaos und Kosmos, whose two parts depend on chronological accounts of different phases of the author's life -- parts counteracting each other through their content rather than their form. In No Return Address, content and form interact conspicuously with controlled association -- i.e., the model of association guided by an engaging narrative scheme, presenting at the same time the recollections of the child, adolescent, or adult and the reflections of the author, the discovering and the discovered self. In this narrative world, the author, as narrator and character, finds an inner and outer stage richly endowed with colorful characters. Vlasopolos's mother supplies much of the focus of this memoir, but others figure also in many humorous and painful episodes, such as the stepfather whom the mother marries and divorces three years after their exodus to the West and whose mendacious antics supply both humor and tragedy, or the vignette of Hertzog, a recent immigrant to Long Island from their Romanian circle (the same friend who had accompanied Vlasopolos's mother to her freezing vigil in front of the prison). Not understanding that one needs a ticket for the Jewish High Holidays, he ends up praying in his car -- a scene that illustrates the theme of displacement with some humor and sadness. The most tragic emotional displacement is undoubtedly the death of Vlasopolos's father when she was very young.

The last section of No Return Address, like the second part in Zwischen Chaos und Kosmos, represents a crucial counterweight to the earlier chapters as it deals with the ultimate dislocation in America. But unlike Picard's memoir, Vlasopolos's does not present a neat divide. Episodes from the future in the West appear in the Romanian sections, while scenes from Romania occur towards the end as well. The trauma of adjustment to Detroit provides the structure into which the main themes of childhood and adolescence in Bucharest and Paris are skillfully folded. In a final experience of displacement, Vlasopolos and her mother, arriving in Detroit, are rejected by their "Ameri- 
can" relatives who regard them as threats coming from a despised past to undermine their carefully nurtured status as part of the American middle class. And yet a further displacement awaited them in rural Michigan, where her mother and stepfather taught for two years in a small high school and where the teen-aged Anca had to undergo more indignities and disappointments while finding new friends. Still, her success in overcoming barriers and at last carving out a place for herself and her family in Detroit and its university is confirmed richly by her strong friendships, her later life among poets and artists, and success with students and scholars, who continue to form the substance of her life as a professor and writer.

The book traces a full circle, as good poems often do, from the Paris metro of the first page to the church of St. Roch, where Vlasopolos takes her daughter to pay tribute to her now-deceased mother: "Here, too, renovation has closed down most of the nave and played tricks with the interior of my own St. Roch, so that what I see is a dismembering. But the side chapel is open and I light a candle, here in a catholic church where my mother over a quarter of a century ago stood next to me and read the moving inscription, for my mother, for my daughter whom I am able to bring to this place for the time being while the memory and these stones last" (220). In No Return Address Vlasopolos builds with living stones, for she has put St. Peter's words to a different use: "And, like living stones, let yourselves be built into a spiritual house." However, here the living stones are Vlasopolos's words that create a temple of lyrical prose, a tribute to a lost culture, lost people, her lost mother, lost love -- and yet not lost, for she has created it here.

The two books under review present two different aspects in time and circumstance during the excruciating mid-twentieth century -- a legacy against which we are struggling today. Ernst Robert Picard's memoir is that of a man now in his seventies who had grown up as part of the 3rd Reich and reached maturity at the time of stabilization of the German experience during the second half of the last century. His memoir -- for all his generous liberal spirit and high culture -- still remains embedded in the political and cultural establishment that had fashioned him. Anca Vlasopolos, by contrast, a woman in her fifties, grew up under precarious circumstances, as the child of a Jewish mother and a Greek father in communist Romania -- the mother an outsider by virtue of her Jewishness, her father an outsider by virtue of his history as an early communist activist purged by the regime. Vlasopolos thus exemplifies displacment as part of an ethnic and religious underclass. However, both authors have achieved a similar social and professional status as university professors, one continuins to bear the mark of the establishment, the other identified with the victims of oppression. And yet (which gives the comparison its edge), immersed in music and painting, both represent the culture of our time.

Reviewer's Profile: Ralph Freedman is professor emeritus of German and comparative literature at Princeton University. A renown scholar of German literature, his many publications include The Lyrical Novel: Studies in Hermann Hesse, Andre Gide and Virginia Woolf (Princeton UP, 1963, 1966-71), translated into several languages, including Korean, Hermann Hesse: Pilgrim of Crisis (Pantheon Books, 1978, Fromm's International Publishers, 1997), Rainer Maria Rilke: Life of a Poet (Farrar, Straus \& Giroux, 1996; Northwestern UP, 1998), Rilke. La vie d'un poete (Actes Sud, 1998), Rainer Maria Rilke. Der junge Dichter (Insel Verlag 2001), and Der Meister (Insel Verlag 2002). Freedman taught at the University of Iowa 1953-65, at Princeton University 1965-88, at Emory University 1988-90, and held visiting professorhips at a number of universities, including the University of Wisconsin, SUNY at Buffalo, and the University of Southern California. In 2002 Freedman received the City of Calw medal for distinguished scholarship on Hermann Hesse. Early in his career, Freedman published a novel, Divided (Dutton, 1948), which won the Lewis and Clark Northwest Award. Recently, he finished another novel, Mark of the Tooth, as of yet unpublished. Email: <rfreed@mindspring.com>. 